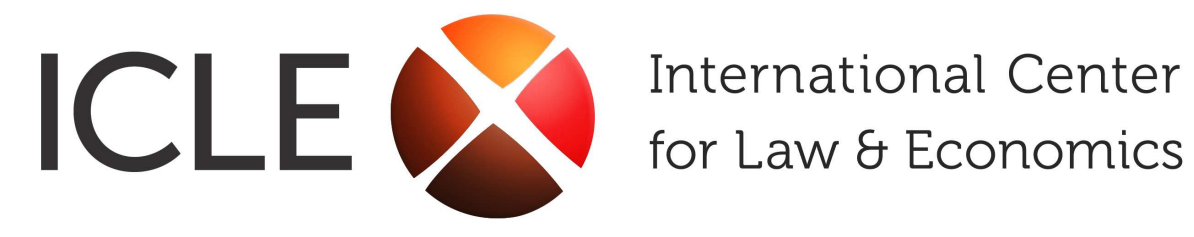

\title{
Significant Impediment to Industry Innovation: A Novel Theory of Harm in EU Merger Control?
}

Nicolas Petit

ICLE Antitrust \& Consumer Protection Research Program White Paper 20l7-I 


\section{Significant Impediment to Industry Innovation:A Novel Theory of Harm in EU Merger Control?}

\section{Nicolas Petit*}

\section{Introduction}

A novel theory of harm is crystalising in European Union ("EU") merger control. Under this theory, the EU Commission ("Commission") can intervene in mergers that it considers generally reduce innovation incentives in an industry as a whole. This theory of harm can be referred to as the Significant Impediment to Industry Innovation ("SIII") theory.

This policy paper first attempts to describe the content and extent of the SIII theory (I). Second, it shows that the SIII theory marks a departure from established EU merger control practice (II). Third, it discusses the economic foundations of the SIII theory (III). Finally, it puts forward best practices for the assessment of mergers in R\&D intensive industries (IV). With this, the present paper hopes to assist in the development of sound merger control policy in innovative markets, and undermine crude conjectures on the relationship between market structure, patent statistics and industry innovation theory.

\section{The Theory: Unpacking SIII}

Recent statements by the Commission point towards the emergence of a novel theory of harm in merger control. In short, the theory provides that a merger can

\footnotetext{
* Professor, University of Liege (ULg), Liege Competition and Innovation Institute ("LCII"); Senior Scholar, International Center for Law and Economics ("ICLE"). ICLE, which provided generous support for this work, is a nonprofit, nonpartisan research center based in Portland, OR, USA. ICLE, in turn, receives financial support from numerous companies, organizations and individuals in the form of unrestricted, general-support donations. The ideas expressed here are the authors' own and do not necessarily reflect the views of ICLE's advisors, affiliates or donors. Please contact the author with questions or comments at nicolas.petit@ulg.ac.be.
} 
and should be prohibited where it can be demonstrated that it will "lead to a reduction of innovation" in a given industry "as a whole."

The roots of the SIII theory can be found in the Commission's Horizontal Merger Guidelines which state that "effective competition may be significantly impeded by a merger between two important innovators." ${ }^{2}$ To date, this sentence had been interpreted as allowing the Commission to intervene in mergers that would give rise to a reduction in $R \& D$ expenditure in relation to specific foreseeable product applications (either because the merging parties develop so-called "pipeline" products or because the merger leads to the elimination of a potential competitor visà-vis an existing product market). ${ }^{3}$ However, the application of the SIII theory of harm would extend the reach of the EU Merger Regulation ${ }^{4}$ to any transaction that will lead to a "general reduction in RED in an industry."

This new theory seems to draw inspiration from a 2016 research paper by economists Justus Haucap and Joel Stiebale, ${ }^{6}$ and a subsequent policy paper published

\footnotetext{
${ }^{1}$ See Directorate-General for Competition ("DG COMP"), Press release: Commission opens in-depth investigation into proposed merger between Dow and DuPont, 11 August 2016, available at http://europa.eu/rapid/press-release IP-16-2784 en.htm.

${ }^{2}$ European Commission, Assessment of Horizontal Mergers Under Council Regulation (EC) No. 139/2004 of 5 May 2004, Guidelines on the assessment of horizontal mergers under the Council Regulation on the Control of Concentrations Between Undertakings ("Horizontal Merger Guidelines"), paras. 20(b) and 38, 2004 O.J. (C 31) 7, 9, available at http://eur-lex.europa.eu/legal-content/EN/TXT/PDF/?uri=CELEX:52004XC0205(02)\& from=EN.

${ }^{3}$ European Commission, DG Competition, Competition policy brief: EU Merger Control and Innovation, April 2016, available at http://ec.europa.eu/competition/publications/cpb/2016/2016_001_en.pdf. See also Raphaël De Coninck, Innovation in EU merger control: in need of a consistent framework, Symposium: Competition and Innovation, Competition Law Policy and Debate, Volume 2, Issue 3, September 2016, available at https://www.crai.com/sites/default/files/publications/Innovation-in-EU. merger-control-in-a-need-of-a-consistent-framework.pdf.

${ }^{4}$ Council Regulation (EC) No 139/2004 of 20 January 2004 on the control of concentrations between undertakings ("EU Merger Regulation"), 2004 O.J. (L 24) 1, available at http://eur-lex.europa.eu/legal-content/EN/TXT/PDF/?uri=CELEX:32004R0139\& from=EN.

${ }^{5}$ Dow DuPont Challenge EU's View of "Innovation," MLEX, 7 September 2016; Comment: Dow, DuPont deal reaches tipping point in Brussels, MLEX, 13 January 2017; Patents Said to Be Scrutinized as EU Weighs Deal, BloOmBerg, 26 January 2017.

${ }^{6}$ Haucap, Justus, and Joel Stiebale, How Mergers Affect Innovation: Theory and Evidence from the Pharmaceutical Industry, Discussion Paper No. 218, Düsseldorf Institute of Competition Economics (“DICE"), April 2016, available at http://www.dice.hhu.de/fileadmin/redaktion/Fakultaeten/Wirtschaftswissenschaftliche Fakultaet/DICE/Discussion Paper/218_Haucap_Stiebale.pdf.
} 
in the Harvard Business Review (hereafter, the "papers"). ${ }^{7}$ The main thrust of the papers can be distilled into three points. First, mergers in $R \& D$ intensive industries not only reduce the innovation incentives of the merging parties, but also decrease their competitors' innovation incentives. Second, competition agencies should focus on the "innovation activities" of industry participants, instead of looking at specific present and/or future product and/or technology markets. ${ }^{8}$ The notion of innovation activities seems to refer to asset-specific investments in upstream innovation inputs. Third, general "innovation activities" are measured by $R \& D$ expenditure and $R \& D$ intensity. Both indicators act as good proxies to gauge the innovation incentives of the merged entity and/or its competitors. The papers conclude by advocating for a less lenient treatment of horizontal concentration in $R \& D$ intensive industries, and call on competition agencies to intervene where mergers are predicted to lead to a reduction of innovative activities in an industry "as a whole."

According to external observers, the SIII theory is being applied by the Commission in relation to horizontal mergers, and, in particular, as part of its ongoing investigation of the Dow/DuPont merger, which (as of the end of January 2017) hangs in the balance. More specifically, it is reported that the Commission is pursuing an innovation theory of harm that is not anchored in specific product markets and/or a pipeline of innovative products, but a general reduction of innovation competition intensity in crop protection. ${ }^{9}$ In essence, the Commission is said to be considering a simple question: post-transaction, will there be a reduction of $R \& D$ expenditure in the industry? If this emerging policy is confirmed, the SIII theory may well be applied to other merger transactions in R\&D-driven industries, with the pharmaceutical sector being most obviously in the crosshairs.

\section{Merger Practice}

To date, the Commission has never intervened in or prohibited a merger purely on the basis of a general "reduction of innovation" activities in an industry "as a

\footnotetext{
${ }^{7}$ Haucap, Justus, and Joel Stiebale, Research: Innovation Suffers When Drug Companies Merge, HARVARD BUSINESS REVIEW, 3 August 2016, available at https://hbr.org/2016/08/research-innovation-sufferswhen-drug-companies-merge.

${ }^{8}$ DG COMP Director-General Johannes Laitenberger has stressed that the Commission is able to take into account "the innovation potential of the merging firms regardless of their current market position." See Johannes Laitenberger, Competition and Innovation, CRA Annual Conference, Brussels, 9 December 2015, available at http://ec.europa.eu/competition/speeches/text/sp2015_04_en.pdf.

${ }^{9}$ Dow DuPont Challenge EU's View of Innovation, op cit.
} 
whole." On the contrary, the practice has been to intervene in mergers that may lead to a reduction of innovation competition through the combination of firms with strong capabilities to innovate in a specific direction. This paper discusses a few representative cases (1), and then provides some context (2). ${ }^{10}$

\section{A. Cases}

In Pasteur-Mérieux/Merck, two pharmaceutical firms wanted to establish a joint venture ("JV"), to combine their human vaccines and related activities. ${ }^{11}$ The Commission noted that the JV would only take over the post-Phase II clinical trials, and that the parties would remain autonomous in their basic $R \& D$ decisions. However, the bylaws of the JV provided that the R\&D strategy of the JV and the parents for the benefit of the JV would be overseen by a development committee. As part of this oversight function, the R\&D activities of the parents, including communications concerning discoveries, would be discussed within the committee. Consequently, it could not be excluded that these discussions would lead to the coordination of the basic $R \& D$ decisions of the merging parties. Therefore, the Commission found that the JV was likely to have an appreciable effect on R\&D for future pipeline products. ${ }^{12}$ But it nonetheless issued an exemption decision due to efficiency gains. According to Glader, Pasteur-Mérieux/Merckx represents the "most extreme line of REDD competition analysis," and it is "certainly not the typical situation." ${ }^{13}$ Yet, the analysis carried out in Pasteur Mérieux/Merck is not tantamount to an SIII analysis. It focuses on the merging parties' innovation in-

\footnotetext{
${ }^{10}$ The cases discussed in this paper are limited to those in which a formal decision has already been published. We understand however that innovation effects have been assessed in some more recent transactions where the decisions are not yet publicly available, or where the case was withdrawn and a decision was never issued (e.g., General Electric/Alstom, Novartis/Glaxo Smith Kline's Oncology Business, Halliburton/Baker Hughes). For more on some of these cases, see De Coninck, Innovation in EU merger control: in need of a consistent framework, op cit.; DG Competition, Competition policy brief: EU Merger Control and Innovation, op cit.

${ }^{11}$ Commission Decision, Case IV/34.776 of 6 October 1994, Pasteur Merieux-Merck, 1994 O.J. (L 309), available at http://eur-lex.europa.eu/legal-content/EN/TXT/PDF/?uri=CELEX:31994D0770\& from=EN. The decision is formally based on Article 101, because it was issued in 1994, prior to the entry into force of the revised EU Merger Regulation in 1997.

${ }^{12}$ Ibid., para. 64.

${ }^{13}$ Marcus Glader, InNOVATION Markets ANd COMPETITION ANALYSIS: EU COMPETITION LAW AND US ANTITRUST LAW (2006), page 164.
} 
centives. And the analysis is expressly framed by reference to specific future pipeline products, namely monovalent vaccines, not the (human) vaccines industry as a whole.

In Glaxo/Wellcome, the Commission scrutinized the effect of the merger of two pharmaceutical companies "in the area of REDD." ${ }^{14}$ The Commission's analysis focused on HIV/AIDS therapeutics, where it found "overlaps" in the parties' R\&D activities. ${ }^{15}$ Ultimately, it concluded that the transaction would not give rise to competitive concerns, and issued a Phase I clearance decision. In particular, the Commission considered that in the absence of a definitive treatment for HIV/AIDS, the merger was not likely to significantly inhibit the research for effective compounds being undertaken by other pharmaceutical companies worldwide. ${ }^{16}$ To some extent, Glaxo/Wellcome has elements of an SIII analysis, insofar as the decision considers the effect of the merger on third parties' incentives to innovate. At the same time, however, the decision is not entirely consistent with SIII. The approach that was followed to assess a potential reduction of innovation incentives shows that it is necessary to delineate a specific upstream $R \& D$ sector. ${ }^{17}$ Moreover, the decision suggests that in cases where potential commercial/therapeutic applications cannot (yet) be identified, mergers have no adverse effect on innovation $R \& D$ incentives.

In Bayer/Aventis Crop Science, the Commission noted from the outset that there are reasons to be concerned about "the grouping of companies with strength in RED and innovation." ${ }^{18}$ In turn, the Commission sought to assess the effect of the transaction on the parties' "RED capabilities and incentives," in relation to specific "current product markets and future product markets." ${ }^{19}$ Put differently, the Commission's assessment of $R \& D$ incentives was undertaken at the more granular level of defined antitrust markets.

\footnotetext{
${ }^{14}$ Merger Procedure Article 6(1)b Non-Opposition Decision of 28 February 1995, Case IV/M.555, Glaxo/Wellcome, para. 18, 1995 O.J. (C 065) 6, available at http://ec.europa.eu/competition/mergers/cases/decisions/m555_en.pdf.

${ }^{15}$ Ibid., para. 33.

${ }^{16}$ Ibid.

${ }^{17}$ GLADER, INNOVATION MARKETS AND COMPETITION ANALYSIS EU COMPETITION LAW AND US AN. TITRUST LAW, op cit.

${ }^{18}$ Commission Decision, Case COMP/M.2547 of 12 July 2000, Bayer/Aventis Crop Science, para. 18, available at http://ec.europa.eu/competition/mergers/cases/decisions/m2547_en.pdf.

${ }^{19} \mathrm{Ibid}$.
} 
In Glaxo Wellcome/SmithKline Beecham, the Commission took the view that it was necessary to assess the impact of the transaction on "RED markets." ${ }^{20}$ As part of its assessment, the Commission considered whether the combination of two pharmaceutical companies would lead to a reduction of the "overall RED potential" in the development of treatments for "Chronic Obstructive Pulmonary Disease" ("COPD"). ${ }^{21}$ The Commission noted there was a considerable "unmet clinical need in this segment" because none of the current or pipeline products acted as an "effective single treatment for COPD." 22 As in Glaxo/Wellcome, the Commission hinted that the lack of foreseeable therapeutic application was a factor that was likely to incentivize $R \& D$, rather than to diminish it. ${ }^{23}$

Syngenta/Monsanto's Sunflower Seed Business is another case where innovation incentives were scrutinized. ${ }^{24}$ Here, the results of the market investigation indicated that the transaction would have led to the removal of a "strong innovative market player." ${ }^{25}$ The Commission considered whether the post-transaction merged entity would have had the ability and incentive to foreclose other breeders from access to its extensive germplasm portfolio, a key biotechnological input. The adoption of such a foreclosure strategy by the merged entity would have undermined the ability of smaller competitors to innovate in the market for the commercialisation of sunflower hybrids in Spain and Hungary. Ultimately, farmers would have suffered from reduced choice compared to the situation that would have prevailed absent the concentration. ${ }^{26}$

In addition to this input foreclosure theory of harm, the text of the decision suggests that increased concentration could lead to a lower rate of innovation. In particular, in its assessment of the effects of the transaction on the Hungarian

\footnotetext{
${ }^{20}$ Merger Procedure Article 6(1)b Non-Opposition Decision, Case COMP/M.1846 of 8 May 2000, Glaxo Wellcome/SmithKline Beecham, para. 174, available at http://ec.europa.eu/competition/mergers/cases/decisions/m1846 en.pdf.

${ }^{21}$ Ibid., paras. 179-188.

22 Ibid., para. 187.

${ }^{23}$ Ibid., para. 188. This was confirmed by the large number of "pipeline products and resourceful competitors on the market."

${ }^{24}$ Commission Decision Case COMP/M.5675 of 17 November 2010, Syngenta/Monsanto's Sunflower Seed Business, available at http://ec.europa.eu/competition/mergers/cases/decisions/m5675_20101117_20600_1556193_EN.pdf.

${ }^{25}$ Ibid., para. 248.

${ }^{26}$ Ibid., paras. 200 and 207.
} 
market for the commercialisation of sunflower hybrids, the Commission concluded that the transaction was "likely to have a negative impact on innovation by eliminating the competitive constraint that the breeding programme and the germplasm of Monsanto exerted on Syngenta and on other competitors to regularly bring new improved varieties into the market." ${ }^{\text {27 }}$ It is, however, not entirely clear to what extent this finding influenced the Commission's view that the transaction would have impeded effective competition in Hungary.

\section{B. Context}

The consistent practice of the Commission is not to disregard the effect of market concentration on innovation incentives. It is taken into account. However, the Commission's assessment of innovation effects has never been undertaken at the general industry or sector level. Rather, innovation incentives are systematically assessed with "specific ties to a well-defined current or future market." 28

Interestingly, the Commission's decisional practice can be contrasted with the limited experience of U.S. antitrust agencies, where the analysis has occasionally focused on situations where a merger would be deemed injurious to competition on separate upstream "innovation markets" that are not directly linked to a downstream current or future product market. ${ }^{29}$ The development of an "innovation markets" framework in U.S. merger control enables regulators to look at the effect of a merger on the "REDD process itself," and on firms' ability and incentives to commit resources to $R \& D$ activities. In contrast to the SIII theory, the delineation of separate upstream $R \& D$ markets where firms compete through investments for future technological applications is a key component of the "innovation markets" framework. ${ }^{30}$

This analysis is interesting in that the identification of separate upstream innovation markets implicitly recognises that the players active in those markets are not necessarily the same as those that compete with the merging parties in downstream product markets. Upstream innovation markets are often characterised by

\footnotetext{
${ }^{27}$ Ibid., para. 321.

${ }^{28}$ See De Coninck, Innovation in EU merger control: in need of a consistent framework, op cit., page 48.

${ }^{29}$ Richard J. Gilbert and Steven C. Sunshine, Incorporating dynamic efficiency concerns in merger analysis: The use of innovation markets, ANTITRUST LAW JOURNAL, Volume 63, Number 2 (1995), pages 569-601.

${ }^{30} \mathrm{Ibid}$.
} 
a wider pool of participants, including, inter alia, public and private research institutions and tech start-ups. Participants in upstream discovery markets are not necessarily active in the commercialisation of their innovations. ${ }^{31}$

The Commission's decisions in Glaxo Wellcome/SmithKline Beecham and Syngenta/Monsanto's Sunflower Seed Business may give the impression that a certain degree of "innovation markets" analysis has been undertaken in EU merger control cases; and that the EU Merger Regulation provides a framework that accommodates an SIII-type analysis. Yet, a careful examination of the Commission's decisional practice compels a different conclusion. Indeed, a review of EU merger control decisions suggests that the Commission's theories of harm have never been predicated on the adverse effect of a transaction on R\&D markets. In Glaxo Wellcome/SmithKline Beecham, the Commission dismissed concerns of adverse effects on R\&D markets. ${ }^{32}$ And the statement in Syngenta/Monsanto's Sunflower Seed Business reads as a laconic endorsement of one of several negative views that were gathered from third parties during the market investigation. In addition, there is no suggestion in either of the decisions that the Commission assessed whether the transaction would lead to a reduction in the $R \& D$ spend/innovation incentives of the merged entity, its rivals and/or of the whole industry, as required under the U.S. "innovation markets" framework. In a 2016 article, two Commission officials reached a similar conclusion stating that "innovation markets" analysis was not a part of EU merger control policy. ${ }^{33}$

Moreover, this interpretation of the application of the EU Merger Regulation is consistent with the approach followed by the Commission in other areas of EU competition law. In particular, the application of the prohibition against anticom-

\footnotetext{
${ }^{31}$ In some cases, it is unfeasible to do so because of the time and cost associated with bringing a product to market (e.g. regulatory approvals for pharmaceutical products). Therefore, it is not uncommon for upstream innovators to rely on larger businesses with a downstream market presence and the necessary scale to monetise (and fund) their $R \& D$ activities. The importance of this symbiotic relationship should not be downplayed, and needs to be taken into account in the assessment of a merger's impact on the "REDD process itself."

32 Glaxo Wellcome/SmithKline Beecham, op cit.

${ }^{33}$ According to Sebastian Müller and Arthur Stril of the Commission's Directorate-General for Competition ("DG COMP"), "Whilst other competition authorities such as the U.S. antitrust agencies have defined and assessed innovation markets in the past, the Commission has not." See Sebastian Müller and Arthur Stril, European Merger Control and Innovation Competition: Moving the Goalpost, Symposium: Competition and Innovation, COMPeTITION LAW POLICY AND Debate, Volume 2, Issue 3, September 2016, page 53 .
} 
petitive agreements to $R \& D$ co-operation between competitors where "in the $a b$ sence of exceptional circumstances, the Commission would not try to assess the impact of a given RED co-operation on innovation, but would limit its assessment to existing product and/or technology markets which are related to the RED co-operation in question." 34

Against this background, it follows that the introduction of the SIII theory to EU merger control would be a quantum leap. Is this warranted?

\section{Economics}

\section{A. Theory}

Advances in economics and our understanding of markets may justify changes to established merger control practice. But any such change can only be justified where two conditions are fulfilled. First, the legal framework must permit it. Practical guidance on the application of EU merger control rules is primarily contained in soft law instruments (for example, the Horizontal Merger Guidelines), which contain significant caveats, and resort to examples instead of principled statements. ${ }^{35}$ The Commission therefore enjoys wide discretion and is able to depart from its previous practice and/or the principles set out in its guidelines, as long as it does not frustrate "legitimate expectations." 36

Second, changes to merger control practice should be based on sound economic arguments backed by empirical evidence. With this, it is instructive to look at the economic foundation of the SIII theory of harm. As is well known, the relationship between firm size, market structure and innovation has remained unsettled in economic theory since Joseph Schumpeter. ${ }^{37}$ In the scholarship, this issue can be compared with Hilbert's problems or Fermat's last theorem for mathematicians: it keeps attracting the interest of the finest experts, including a host of

\footnotetext{
${ }^{34}$ See European Commission, Guidelines on the applicability of Article 101 of the Treaty on the Functioning of the European Union to horizontal cooperation agreements ("Horizontal Cooperation Guidelines"), 2011 O.J. (C 11), paras. 122, 26, available at http://eur-lex.europa.eu/legal-content/EN/TXT/PDF/?uri=CELEX:52011XC0114(04)\& from=EN.

${ }^{35}$ In relation to the topic of this paper, see Horizontal Merger Guidelines, op cit., paragraph 20(b).

${ }^{36}$ Nicolas Petit and Miguel Rato, From Hard to Soft Enforcement of EC Competition Law - A Bestiary of 'Sunshine' Enforcement Instruments (2008), page 4, available at https://papers.ssrn.com/sol3/papers.cfm?abstract id $=1270109$.

${ }^{37}$ JOSEPH SCHUMPETER, CAPITALISM, SOCIALISM AND DEMOCRACY (1942).
} 
Nobel Prize winners such as Stiglitz, ${ }^{38}$ Phelps,${ }^{39}$ Stigler, ${ }^{40}$ Arrow, ${ }^{41}$ and probably more to come. In recent years, improvements in our understanding of economics have been achieved through theoretical and empirical studies (to which Haucap and Stiebale contribute). ${ }^{42}$ Yet, unlike other areas where economic research has yielded policy outcomes that are now a part of antitrust orthodoxy, e.g., the positive relationship between industry concentration and collusion, it is not possible to draw presumptive conclusions on the link between concentration and innovation. $^{43}$

Against this backdrop, Katz and Shelanski recommend that inquiries "about the effects of specific transactions within a particular industry based on a fact-intensive investigation into the incentives and capabilities of actual and potential innovators." 44 In doing so, they underline that "such fact-intensive, case-by-case inquiries are the better course than the systematic retreat from enforcement in dynamic settings for which the 'Schumpeterian' school argues."

\section{B. Application}

Let us try to understand the implications of Katz and Shelanski's best principles for the assessment of mergers in $R \& D$ driven industries. ${ }^{45}$ To keep the analysis sufficiently concrete, let us focus on the seed and agrochemical industry where ongoing mergers could be potentially candidates for a SIII risk assessment in the

\footnotetext{
${ }^{38}$ Partha Dasgupta and Joseph Stiglitz, Industrial Structure and the Nature of Innovative Activity, ECO. NOMIC JOURNAL, Volume 90, Issue 358 (1980), pages 266-293.

${ }^{39}$ Edmund S. Phelps, Toward a Model of Innovation and Performance: Along the Lines of Knight, Keynes, Hayek, and M. Polanyi, in Zoltan J. Acs, David B. Audretsch and Robert J. Strom, EntrepreNEURShIP, GROWTH, AND PUBliC POLICY (2008), pages 35-70.

${ }^{40}$ George J. Stigler, Industrial Organization and Economic Progress, in L. D. WhITE, ED., THE STATE OF THE SOCIAL SCIENCES (1956) 269-82.

${ }^{41}$ Kenneth J. Arrow, Economic Welfare and the Allocation of Resources for Invention, in THE RATE AND DIRECTION OF INVENTIVE ACTIVITY: ECONOMIC AND SOCIAL FACTORS (NBER, 1962), pages 609-26.

${ }^{42}$ Carl Shapiro, Competition and Innovation: Did Arrow Hit the Bull's Eye? in JOSH LERNER AND SCOTT Stern, THE RATE AND Direction OF INVENTIVE ACTIVITY REVISITED (2011), pages 361-404; Michael L. Katz, and Howard A. Shelanski, Mergers and Innovation, ANTITRUST LAW JOURNAL Volume 74, Issue 1, (2007), pages 1-85 ("The results suggest that few presumptions can be drawn even if transactions are broken down by industry and by their domestic versus cross-border nature").

${ }^{43}$ Reinhilde Veugelers, Innovation in EU Merger Control: Walking the Talk, BRUEGEL POLICY CONTRIBU. TION, Issue 2012/04, February 2012, page 8, available at http://bruegel.org/wp-content/uploads/imported/publications/pc_2012_04_FINAL.pdf.

${ }^{44}$ Katz and Shelanski, Mergers and Innovation, op cit.

${ }^{45}$ Dow/DuPont, ChemChina/Syngenta and Bayer/Monsanto.
} 
EU. Note that the analysis is preliminary, and only purports to assess if the industry displays features which justify prima facie SIII concerns.

To start, this paper examines empirical data. The two tables below compile high level data on the $R \& D$ expenditure (table 1 ) and $R \& D$ intensity (table 2) of six leading agrochemical companies. These data - which we concede again are high level estimates - have been extracted from the EU Industrial R\&D Scoreboards between 2009 and 2016. ${ }^{46}$ During that timeframe, all six firms clearly increased their total $R \& D$ expenditure. In addition, $R \& D$ intensity during the same period either increased (Syngenta, DuPont, Monsanto) or remained stable (BASF, Bayer and Dow Chemical have maintained a consistent level of $R \& D$ expenditure with a possible $0.1 \%$ variation). Moreover, this increase in $R \& D$ intensity has taken place in spite of a dramatic drop in global agricultural commodity prices, ${ }^{47}$ which has adversely affected several agrochemical businesses. ${ }^{48}$

\footnotetext{
${ }^{46}$ The EU Industrial RED Investment Scorecard, EU Science Hub, Economics of Industrial Research and Innovation, European Commission Joint Research Centre, available at http://iri.jrc.ec.europa.eu/scoreboard.html.

${ }^{47}$ Food commodity Prices Fall for Fifth Year in a Row in 2016, FOOD AND AGRICULTURE ORGANiZATION, 12 January 2016, http://www.fao.org/news/story/en/item/462790/icode/; Global Food Prices Drop to a Five-Year Low, THE WORLD BANK, 1 July 2015, http://www.worldbank.org/en/news/press-release/2015/07/01/global-food-prices-drop-to-a-five-year-low; Emiko Terazono, Agricultural Commodities feel the bite of weaker demand, FinANCIAL TiMES, 12 August 2015, https://www.ft.com/content/0694895a-400f-11e5-b98b-87c7270955cf.

${ }^{48}$ See, e.g., Sheenagh Matthews, BASF Quarterly Profit Hurt by Weak Demand for Crop Chemicals, BLOOMBERG, 27 July 2016, available at https://www.bloomberg.com/news/articles/2016-07-27/basfquarterly-profit-misses-estimates-on-lower-oil-operations; Brian Blackstone, Syngenta Profits Down on Weak Commodity Prices, Global Uncertainty, WALl StreET Journal, 22 July 2016, available at https://www.wsj.com/articles/syngenta-profit-down-on-weak-commodity-prices-global-uncertainty1469172890; Jack Kaskey, Monsanto to Cut 12\% of Workforce as It Forecasts Profit Drop, BloOmBERG, 7 October 2015, available at https://www.bloomberg.com/news/articles/2015-10-07/monsanto-profitforecast-misses-estimates-amid-grain-bear-market; Jack Kaskey, DuPont Cuts Profit Forecast Amid Weaker Agriculture, BLOOMBERG, 28 July 2015, available at https://www.bloomberg.com/news/articles/2015. 07-28/dupont-cuts-profit-forecast-amid-weaker-agriculture.
} 
Table 1

$\begin{array}{lccccccc}\text { R\&D Total mill } & 2009 & 2011 & 2010 & 2012 & 2013 & 2014 & 2015 \\ \text { SYNGENTA } & 669.1 & 769.3 & 871 & 949.7 & 997.8 & 1,177.8 & 1,251.0 \\ \text { BASF } & 1410.0 & 1507.0 & 1622 & 1766.0 & 1,914.0 & 1,846.0 & 1,914.0 \\ \text { BAYER } & 2964.0 & 3211.0 & 3045 & 3182.0 & 4,436.0 & 3,689.0 & 4,436.0 \\ \text { DUPONT } & 960.4 & 1230.7 & 1511.7 & 1566.6 & 1,743.4 & 1,702.5 & 1,743.4 \\ \text { DOW CHEMICAL } & 1039.8 & 1237.4 & 1272.1 & 1294.5 & 1265.3 & 1,356.6 & 1,467.8 \\ \text { MONSANTO } & 765.2 & 898.2 & 1172.4 & 1149.8 & 1,451.3 & 1,413.4 & 1,451.3\end{array}$

Table 2

\begin{tabular}{lccccccc} 
R\&D Intensity \% & 2009 & 2011 & 2010 & 2012 & 2013 & 2014 & 2015 \\
SYNGENTA & 8.7 & 8.9 & 8.5 & 8.8 & 9.4 & 9.4 & 10.2 \\
BASF & 2.8 & 2.4 & 2.2 & 2.2 & 2.5 & 2.5 & 2.7 \\
BAYER & 9.5 & 9.2 & 8.3 & 8.0 & 8.1 & 8.7 & 9.4 \\
DUPONT & 5.3 & 5.2 & 5.2 & 5.9 & 6.0 & 5.9 & 7.5 \\
DOW CHEMICAL & 3.3 & 3.1 & 2.7 & 3.0 & 3.1 & 2.8 & 3.3 \\
MONSANTO & 9.4 & 11.5 & 11.2 & 11.2 & 10.3 & 10.8 & 10.5 \\
\hline
\end{tabular}

The figures in Tables 1 and 2 are not prima facie indicative of a significant risk of reduced innovation incentives due to market concentration, and thus do not support the application of an SIII analysis to mergers in the agrochemical sectors, like Dow/DuPont.

However, empirical data is often not univocal, and dataset interpretation is no exact science. In this regard, the 2016 testimony of Diana Moss, the president of the American Antitrust Institute ("AAI"), before the US Senate Judiciary Committee (the "AAI Testimony"), paints a radically different picture of innovation 
in the U.S. agricultural biotechnology and seeds sector. ${ }^{49}$ The AAI Testimony suggests that agricultural biotechnology and seed markets are already concentrated and marked by "growing evidence of flagging innovation." ${ }^{50}$ In support of the conclusion that "consolidation will eliminate competition in agricultural biotechnology innovation markets," the AAI cites R\&D statistics taken from a study by the U.S. Department of Agriculture ("USDA"). ${ }^{51}$ According to the AAI, those figures show that spending on $R \& D$ in crop seed and biotechnology increased by $138 \%$ between 1994 and 2010. ${ }^{52}$ However, by the late 2000s, R\&D intensity (i.e., the R\&D to sales ratio) dropped to the lower levels experienced in the mid-1990s. This trend led the USDA to conclude that concentration in agricultural input markets is no longer a driver for increased $R \& D$ or $R \& D$ intensity. The AAI relies on this conclusion to call "into question long standing arguments that concentration is needed to generate economies of scale in RED.."53

We have carefully reviewed the AAI Testimony, as well as the background sources that it uses to support its claims. Unfortunately, the AAI Testimony misrepresents the conclusions of the USDA study. ${ }^{54}$ The USDA study expressly states that: "the underlying causes of growing concentration in these sectors appear to be quite specific to each sector and may not have affected private incentives to invest in REDD" (emphasis added). ${ }^{55}$ This is a weak basis to support the radical enforcement initiatives advocated by the AAI report, and, in particular, the prohibition of several high profile

\footnotetext{
${ }^{49}$ Diana Moss (American Antitrust Institute), Consolidation and Competition in the U.S. Seed and Agrochemical Industry, Testimony before the U.S. Senate Judiciary Committee, 20 September 2016, available at https://www.judiciary.senate.gov/imo/media/doc/09-20-16 Moss Testimony.pdf. are incorrect (see footnotes 13 and 15). The USDA statistics that are cited, and in particular the $138 \%$ figure, are attributable to a study cited elsewhere in the AAI Testimony, namely, Keith O. Fuglie et al., Research Investments and Market Structure in the Food Processing, Agricultural Input, and Biofuel Industries Worldwide, Economic Research Report 130, ERS (U.S.D.A. 2011), available at https://www.ers.usda.gov/webdocs/publications/err130/11777_err130_1_.pdf.

${ }^{55}$ Ibid., page 15.
} 
transactions such as the Dow/DuPont and Bayer/Monsanto mergers. ${ }^{56}$ Furthermore, the USDA study goes on to consider the "factors driving consolidation and concentration" in various agricultural input markets. In the crop seed and biotechnology sector, the principal factor driving consolidation is the "[A]cquisition of complementary technology and marketing assets, economics of scale in crop biotechnology REDD." 57

To complete this preliminary empirical assessment, we have turned to analytical sources. An extensive review of the copious economic literature on innovation in the agrochemical and seeds industries has been undertaken. It is remarkable that many papers published in the field seek to nuance the basic premise that $R \& D$ is the main driver of industry innovation in agricultural biotechnology. ${ }^{58}$ Piergiovanni and Santarelli, for instance, note that

$R E D D$ does not represent the sole input through which firms can produce some innovative outcomes.... [E]xpenditures in improved machinery and capital equipment may play a crucial role in the development of new patentable items, a role not necessarily less important than that played by RED expenditures. This implies complementarity rather than substitutability between $R E D$ and capital expenditures, also in a science-based industry such as biotechnology. 59

In the same vein, Pardey, et al. explain that

\footnotetext{
${ }^{56}$ Ibid., page 14 ("We generally expect research investments to be correlated with industry sales (i.e., that research intensity, or the REDD-to-sales ratio, remains stable over time) unless other factors are changing incentives for private REDD. Other factors include (1) expectations that future demand growth will accelerate, (2) advances in scientific knowledge that have created new technological opportunities for commercialization, and (3) stronger IPR or changes in market structure that have made it easier for private RED investors to appropriate economic benefits of new technology").

${ }^{57}$ Ibid., table 1.8 .

${ }^{58}$ This policy paper does not aim to discuss, but rather simply to point out that there are numerous studies that underscore the significant impact of public $R \& D$ on private $R \& D$ and innovation in the agricultural biotechnology space. See, for instance, Innovation, Agricultural Productivity and Sustainability in the United States, OECD, November 2016, page 590 , available at http://www.oecd.org/publications/innovation-agricultural-productivity-and-sustainability-in-the-united-states-9789264264120. en.htm ("One implication of the complementarity between public and private research is that continued robust public investments in science may be necessary to prevent private agricultural RED spending from eventually tapering off").

${ }^{59}$ Roberta Piergiovanni and Enrico Santarelli, The More You Spend, the More You Get? The Effects of REDD and Capital Expenditures on the Patenting Activities of Biotechnology Firms, SCIENTOMETRICS, Volume 94, Issue 2 (2013), pages 497-521.
} 
Research focused on food and agriculture is not the only source of innovation in the sector. The results of public and private research in the broader biological and informatics sciences, engineering, ecology, health, and numerous other areas of inquiry also show up as innovations in food and agriculture (and vice versa). ${ }^{60}$

It follows that there are several sources of agricultural biotechnology innovations, and that they may be the result of disruptive shocks that originate in other fields. ${ }^{61}$

In view of the above, the risk of a reduction of industry innovation due to increased concentration in the agrochemical and seeds industries is far from established; and the case for a departure from merger control practice with the introduction of a novel SIII test is not compelling. The current EU merger control framework, which enables the Commission to conduct a prospective analysis of innovation effects in current or future product markets seems to provide an appropriate safeguard against anticompetitive transactions.

\section{Best Practices}

In conclusion, this paper offers policy recommendations that are intended to guide the assessment of mergers in R\&D-driven industries.

\section{A. Appreciable Effects}

If SIII theory (or innovation markets analysis) is to become a feature of EU merger control practice, a reduction in innovation incentives per se should not trigger enforcement action under the EU control merger rules. The legal test in the EU Merger Regulation stipulates that a "significant impediment to effective competition" must be established. ${ }^{62}$ Moreover, to the extent an impediment to industry innovation can be established, the Commission must demonstrate that such an impediment translates into a significant impediment to effective competition. In order to do so, it would need to be demonstrated that innovation is indeed a competitive parameter in the markets affected by a merger (since firms do not

\footnotetext{
${ }^{60}$ Philip G. Pardey, Connie Chan-Kang, Jason M. Beddow, and Steven P. Dehmer, Long-Run and Global RED Funding Trajectories: The U.S. Farm bill in a Changing Context, AMERICAN JOURNAL OF AGRICUlTURAl ECONOMICS, Volume 97, Issue 5 (2015), pages 1312-1323.

${ }^{61}$ James Mitra, Joyce Tait, and David Wield, From Maturity to Value-added Innovation: Lessons from the Pharmaceutical and Agro-biotechnology Industries, TRENDS IN BIOTECHNOLOGY, Volume 29, Issue 3 (2011), pages 105-109 (noting that the pharmaceutical and agricultural industries are susceptible "to 'technological shocks', as new scientific knowledge and path-breaking technologies broaden the spectrum of options for REDD and strategic management").

${ }^{62}$ See EU Merger Regulation, recitals 24-26.
} 
compete for customers on the basis of their overall $R \& D$ expenditure). No obvious reason justifies - nor has been advanced - to lower the threshold of inquiry to any and all impediments to industry innovation.

In practical terms, we believe that the magnitude of a merger's adverse effects on industry participants' $R \& D$ efforts should not be trivial or transitory in order to warrant regulatory intervention. Additionally, there are better alternatives to using projected $R \& D$ expenditure in order to assess innovation effects. For instance, one possible proxy that could be used as preliminary screening tool is examining whether a merger will negatively impact the classification of a firm on the four-tier "technology group" scale that is conventionally used by $R \& D$ experts. This classification evaluates individual companies by reference to the intensity of their R\&D programmes, distinguishing 'high-technology', 'medium high-technology', 'medium low-technology' and 'low-technology' firms. ${ }^{63}$ For instance, the Commission could, by reference to the parties' internal documents, seek to assess whether a merger between two high-technology firms would lead to the re-classification of the merged entity as a "medium-high" technology firm, e.g., due to the realisation of synergies and the implementation of cost-cutting measures. However, the use of preliminary merger screening tools should never obviate the need to conduct a fact-intensive investigation, including qualitative competitive analyses (see below), in line with the approach advocated by Katz and Shelanski.

\section{B. R\&D and Patent Statistics}

Drawing causal inferences from $R \& D$ figures and patent statistics in a merger control context is dangerous. Take $\underline{R} \& D$ intensity, which measures the ratio of $R \& D$ expenses (numerator) to sales (denominator). This $R \& D$ intensity can increase or decrease for a variety of reasons that do not necessarily correlate with an increase or decrease in the intensity of innovation. It is very difficult to measure or predict innovation. As Veugelers notes, "innovation effects are typically uncertain and become clear only over the medium to long-term." 64

Similar pitfalls affect measures of $\underline{R} \& D$ expenses. Conceptually, $R \& D$ spending can be analogized with investments in inputs. When this is properly understood, decreases in $R \& D$ expenses are consistent with welfare enhancing mergers that

\footnotetext{
${ }^{63}$ See Thomas Jaegers, Carmen Lipp-Lingua and Digna Amil, High-technology versus Low-technology Manufacturing: High-technology and Medium-high Technology Industries Main Drivers of EU-27's Industrial Growth, EUROSTAT: STATISTICS IN FOCUS, January 2013.

${ }^{64}$ Veugelers, Innovation in EU Merger Control: Walking the Talk, op cit., page 4.
} 
yield productivity gains due to a reduction in the consumption of inputs. Put differently, an $R \& D$ efficient merger is one in which a decrease in $R \& D$ input requirements yields constant output (or in which stable $R \& D$ input requirements yield increased output). ${ }^{65}$ The widely-held belief that increasing productivity necessarily requires higher investments, including in $R \& D$, is fundamentally unsound and not based on proper economics. ${ }^{66}$

Regulators should also exercise caution in their reliance on patent counts and/or patent citations to gauge the innovation potential of the merging parties. There are two sets of reasons for this. First, even though patent counts and/or citations are often used by economists to assess the innovation performance of firms, the same economists are well aware that over-reliance on patent counts and/or citations can paint a misleading picture of the parties' strength as innovators in terms of market impact. There are several reasons for that. To start, patents do not necessarily translate into products that are commercialised. Indeed, "there can be a "great gulf between patents filed and what that actually translates on the market." 67

Moreover, although patent counts and/or citations reflect the degree of academic interest that has been generated by a protected technological application, not all patents are equal in terms of commercial value. Accordingly, the use of patent counts/citations as a measure of innovative strength should be limited to instances where the patent clearly has an actual or potential commercial application in those markets that are being assessed. Such an approach would ensure that patents with little or no impact on innovation competition in a market are excluded from consideration. It is also consistent with the Commission's competitive assessment in Glaxo/Wellcome (see above).

Furthermore, patent counts and/or citations are crude numbers that do not discount the temporal value of patents and, in particular, do not say much as to whether the patent is far from or close to its expiry date. This temporal aspect is of significant importance because firms' incentives to innovate may be stronger as a protected technological application approaches patent expiry. With all this,

\footnotetext{
${ }^{65}$ See De Coninck, Innovation in EU merger control: in need of a consistent framework, op cit., page 48 ("In fact, the reduction in RED input can actually be a good thing if it results from synergies that lead to similar or better output").

${ }^{66}$ In his recent speech, Competition and Innovation, Johannes Laitenberger insisted on the role of competition law "in fostering productivity thanks to higher investments, better managerial organisation, and - yes innovation." See Laitenberger, Competition and Innovation, op cit.

${ }^{67}$ Dow-DuPont Patents Said to Be Scrutinized as EU Weighs Deal, op cit.
} 
Hagedoorn and Cloodt note that "[p]atent specialists are somewhat skeptical about the counting of patent citations without the necessary in-depth knowledge necessary to interpret the underlying citation reports that accompany each patent" and rightly recommend that the analysis be undertaken with additional indicators. ${ }^{68}$

Second, it is entirely unclear that increased market concentration gives rise to lower patent counts and/or citations. At the theoretical level, several empirical studies suggest that "firms with strong market positions tended to have higher patent counts, especially in the citation-weighted patent production function." ${ }^{69}$ In a famous 1992 paper called "Schumpeter and Plausible Capitalism," F. M. Scherer, a notable antitrust economist, concluded a review of the literature with the following note: "within the subset of companies, or relatively homogeneous divisions of companies, that do perform $R E D$ and/or receive patents, RED spending and patenting tend to rise approximately linearly with size (measured by sales)." ${ }^{70}$ And from a logical standpoint, one fails to see how a merger of two firms with similar $R \& D$ pipelines can affect patent counts/citations. Or put differently, the number of patent counts/citations is not determined by the degree of interfirm competition.

Suppose firms $A$ and $B$ compete on R\&D in the hope of obtaining a patent for application Z, which will yield 1000 citations. If A wins the race to the patent office, it obtains a patent on $\mathrm{Z}$, at the expense of $\mathrm{B}$. There is just one patent on $\mathrm{Z}$ granted to $\mathrm{A}$, and $\mathrm{B}$ will never get a patent on the $\mathrm{Z}$ application. Conversely, if $\mathrm{B}$ wins the race to the patent office, it earns a patent on the $Z$ application at the expense of $\mathrm{A}$. In both cases, there is only one patent on application $\mathrm{Z}$ that will attract 1000 citations in any scenario. Now, if $A$ and $B$ merge, it is $A B$ that will win the race to the patent office. $A B$ will obtain on patent on $\mathrm{Z}$ which will yield the same amount of citations, i.e. 1000. In this variant, the number of patent counts and citations remains the same. Regardless of the scenario under review - competitive behaviour or a merger transaction - the patent for $\mathrm{Z}$ should generate the same amount of citations.

\footnotetext{
${ }^{68}$ John Hagedoorn and Myriam Cloodt, Measuring innovative performance: is there an advantage in using multiple indicators?, RESEARCH POLICY, Volume 32, Issue 8 (2003), pages 1365-79.

${ }^{69}$ Tom Nicholas, Why Schumpeter was right: innovation, market power, and creative destruction in 1920s America, Journal of ECONOMIC History, Volume 63, Issue 4 (2003), pages 1023-58.

${ }^{70}$ Frederic M. Scherer, Schumpeter and Plausible Capitalism, JOURNAL OF REPRINTS ANTITRUST LAW \& ECONOMICS, Volume 28 (1998), page 759.
} 


\section{Qualitative Analysis}

The limitations encountered with the use of quantitative indicators (e.g., $R \& D$ expenditure, patent counts and/or citations) to assess a merger's effects on innovation make it even more imperative to complement that analysis with qualitative analyses. This is in line with the "fact-intensive, case-by-case inquiries" advocated by Shelanski and Katz to assess the incentives and capabilities of actual and potential innovators. Central to the assessment of the qualitative dimension of innovation competition is an understanding of the key drivers of innovation in an industry. In the agrochemical industry, industry structure and market competition may only be one amongst many other factors that promote innovation. Virtually all studies agree on this. Interestingly, the economic literature on private $R \& D$ in agrochemical markets underlines the important role that is played by public $R \& D$ on innovation incentives and to a much lesser extent competition and rivalry. This may be attributable to the reasons outlined in this paper that expose the difficulty in drawing inferences on the relationship between innovation and market structure. ${ }^{71}$

Moreover, the impact of wider industry and regulatory developments on incentives to innovate and market structure should not be ignored, e.g., falling crop commodity prices, or regulatory restrictions on the use of certain products. In agrochemicals in particular, ceasing to innovate is not an option since plant and pest resistance force market players to keep inventing new products. Last, agencies and regulators should understand that beyond $R \& D$ and patent statistics, there is also a degree of qualitative competition in the innovation strategies that are pursued by agrochemical players. Industry structure as well as internal resources and dynamic capabilities give rise to different innovation strategies: some may be "economizing" (e.g., engaging in replication or imitation), others may be "strategizing" (e.g., engaging in strategic conflict) or both. ${ }^{72}$ It is important to empirically grasp the true nature of such approaches prior to drawing conclusions on the state of innovation competition in a given industry.

\footnotetext{
${ }^{71}$ See, e.g., Pardey, et al., Long-Run and Global REDD Funding Trajectories: The U.S. Farm bill in a Changing Context, op cit. ("For much of modern history, the preponderance of formal global food and agricultural REDD was conducted by public agencies, including government research labs and academic institutions.... [P]ublic RED is more of a complement to private REDD, such that a decline in the performance of public research will have negative consequences for the longer-run rate of innovation in U.S. agriculture.").

72 Joanna Chatawaay, Joyce Tait, and David Wield, Understanding company RED strategies in agro-biotechnology: trajectories and blind spots, RESEARCH POLICY, Volume 33, Issue 6 (2004), pages. 1041-57.
} 


\section{Presumptions}

The appeal of a theory based on a presumption that regulatory intervention is warranted where a merger removes a "parallel path REDD" is not in line with the standard of proof required by the EU Courts in Tetra Laval $v$ Commission. ${ }^{73}$ In that case, the EU Courts held that one could not assume that the disappearance of the target firm's innovative capabilities would lead to a "diminished need" for the acquiring firm "to innovate following implementation of the modified merger." Court insisted that any such conclusion must be based on a thorough market analysis. Particular attention was given to the innovation capabilities of the merged entity's rivals. ${ }^{75}$

Prior to the annulment of its decision in Tetra Laval, the Commission's own decisional practice had carefully avoided relying on a similar presumption. In Glaxo Wellcome/SmithKline Beecham, the Commission accepted the idea that mergers can lead to the abandonment of product development programmes, provided that the level of innovative activities in the overall market remained sufficient. ${ }^{76}$ This approach was, and remains, the right one.

\section{Conclusion}

Much as there is no clear link between market concentration and industry innovation, "the academic literature shows there is no automatic relationship between mergers and innovation." 77 This finding should lead any humble antitrust analyst to accept that the question remains largely an empirical matter.

From a policy standpoint, our findings suggest that the application of a theory in merger control that draws a potential negative link between increased industry concentration and incentives to innovate (like SIII) should be balanced by an

\footnotetext{
${ }^{73}$ Case T-5/02, Tetra Laval v Commission, 2002 E.C.R. II-4381, http://curia.europa.eu/juris/showPdf.jsf.docid $=86672 \&$ doclang $=E N$. Judgment of General Court upheld by Court of Justice in Case C-12/03, P Commission v Tetra Laval, 2005 E.C.R. I-987, http://curia.europa.eu/juris/showPdf.jsf?text=\&docid $=49926 \&$ pageIn $\mathrm{dex}=0 \&$ doclang $=E N \&$ mode $=1 \mathrm{st} \&$ dir $=\&$ occ $=$ first $\&$ part $=1 \&$ cid $=412738$.

${ }^{74}$ Case T-5/02, Tetra Laval v Commission, op cit., para. 329.

${ }^{75}$ Ibid., para. 330.

${ }^{76}$ Glaxo Wellcome/SmithKline Beecham, op cit, para. 188 ("While it is feasible to believe that the parties will streamline their RED efforts in the future, given the large number of current pipeline products and resourceful competitors on the market, the Commission does not consider that this would lead to the diminution of the overall RED potential either.").

${ }^{77}$ Veugelers, Innovation in EU Merger Control: Walking the Talk, op cit., page 8.
} 
equivalent theory that assesses a potential increase in innovation. To put things differently, if the Commission wants to introduce a SIII theory to its merger control practice, then this theory should cut both ways and test not only a "Significant Impediment to Industry Innovation" but also a "Significant Increase in Industry Innovation." 